\title{
Teaching Video NeuroImages: Tongue myokymia in hypoglossal neuropathy
}

Tze Chao Wee, MBBS, FAFRM(RACP), FFPMANZCA, Romesh Markus, MBChB(Hons), PhD, FRACP, FAHA, and Neil G. Simon, BSc Med(Hons), MBBS(Hons), PhD, FRACP

Neurology ${ }^{\circledR}$ 2019;93:e214. doi:10.1212/WNL.0000000000007756

A 50-year-old woman presented with painless dysphagia and dysarthria. There was no radiation exposure. Examination revealed involuntary tongue movements and reduced bulk with deviation to the right on protrusion. The remaining neurologic examination was normal. MRI brain/skull base with contrast was normal.

Ultrasound examination before EMG demonstrated abnormal tongue movement along with the sonographic anatomy of the submental muscles and tongue (video 1$).{ }^{1}$ Ultrasound allows for dynamic assessment of the tongue, which is otherwise impossible with other imaging techniques. ${ }^{2}$ Right genioglossus EMG confirmed myokymia and sparse fasciculations with background chronic neurogenic motor unit rearrangement and reduced recruitment.

The diagnosis was chronic idiopathic hypoglossal neuropathy with clinical remission but subsequent deterioration due to the development of nerve hyperexcitability.

\section{Author contributions}

T.C. Wee: drafting/revising the manuscript, data acquisition, study concept or design, accepts responsibility for conduct of research and final approval. R. Markus: drafting/revising the manuscript, data acquisition, analysis or interpretation of data, accepts responsibility for conduct of research and final approval. N.G. Simon: drafting/revising the manuscript, data acquisition, study concept or design, analysis or interpretation of data, accepts responsibility for conduct of research and final approval, acquisition of data, study supervision.

\section{Study funding}

No targeted funding reported.

\section{Disclosure}

The authors report no disclosures relevant to the manuscript. Go to Neurology.org/N for full disclosures.

\section{References}

1. Van Den Engel-Hoek L, Van Alfen N, De Swart BJ, De Groot IJ, Pillen S. Quantitative ultrasound of the tongue and submental muscles in children and young adults. Muscle Nerve 2012;46:31-37.

2. Simon NG. Dynamic muscle ultrasound: another extension of the clinical examination. Clin Neurophysiol 2015;126:1466-1467.

\section{Correspondence}

Dr. Simon

n.simon@unsw.edu.au

\section{MORE ONLINE}

- Video

$\rightarrow$ Teaching slides

links.lww.com/WNL/

A918

From the Department of Rehabilitation Medicine (T.C.W.), Changi General Hospital, Singapore; and the Department of Neurology (R.M., N.S.), St Vincent's Hospital, Darlinghurst, New South Wales, Australia.

Go to Neurology.org/N for full disclosures. 


\section{Neurology}

\section{Teaching Video NeuroImages: Tongue myokymia in hypoglossal neuropathy}

Tze Chao Wee, Romesh Markus and Neil G. Simon

Neurology 2019;93; 214

DOI 10.1212/WNL.0000000000007756

\section{This information is current as of July 8, 2019}

\section{Updated Information \& Services}

\section{References}

Subspecialty Collections

Permissions \& Licensing

Reprints including high resolution figures, can be found at: http://n.neurology.org/content/93/2/e214.full

This article cites 2 articles, 0 of which you can access for free at: http://n.neurology.org/content/93/2/e214.full\#ref-list-1

This article, along with others on similar topics, appears in the following collection(s):

\section{All Movement Disorders}

http://n.neurology.org/cgi/collection/all_movement_disorders Clinical neurology examination

http://n.neurology.org/cgi/collection/clinical_neurology_examination Cranial neuropathy

http://n.neurology.org/cgi/collection/cranial_neuropathy

\section{EMG}

http://n.neurology.org/cgi/collection/emg

Ultrasound

http://n.neurology.org/cgi/collection/ultrasound

Information about reproducing this article in parts (figures,tables) or in its entirety can be found online at:

http://www.neurology.org/about/about_the_journal\#permissions

Information about ordering reprints can be found online:

http://n.neurology.org/subscribers/advertise

Neurology ${ }^{\circledR}$ is the official journal of the American Academy of Neurology. Published continuously since 1951, it is now a weekly with 48 issues per year. Copyright @ 2019 American Academy of Neurology. All rights reserved. Print ISSN: 0028-3878. Online ISSN: 1526-632X.

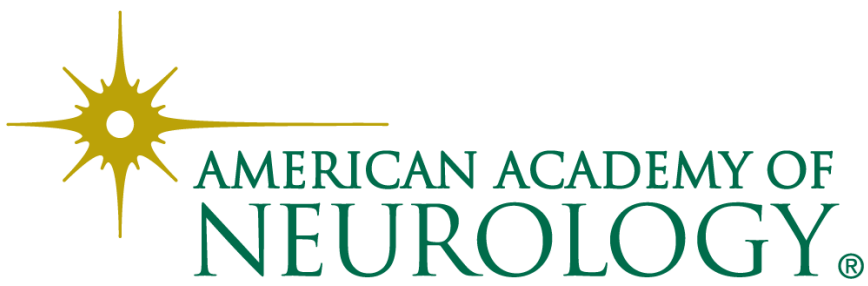

